\title{
AC 2007-247: THE EVOLUTION OF THE EDGE PROGRAM IN ITS FOURTH YEAR
}

\section{Dan Dimitriu, San Antonio College}

DAN G. DIMITRIU has been practicing engineering since 1970 and taught engineering courses concurrently for over 20 years. He has been involved with several engineering societies and was elected vice-chair of the Two-Year College Division of ASEE in 2005. He has been the coordinator of the Engineering Program at San Antonio College since 2001. His research interests are: alternative fuels, fuel cells, plastics, and engineering education.

\section{Jerry O'Connor, San Antonio College}

JERRY O'CONNOR has been teaching physics (and a few engineering courses) at San Antonio College since 1987. He is currently the Department Chairperson for Physics, Engineering, \& Architecture and a member of the AAPT Committee on Physics in Two Year Colleges. His primary professional interest is in the integration of the findings of physics and engineering education research with education practice. 


\section{THE EVOLUTION OF THE EDGE PROGRAM IN ITS FOURTH YEAR}

This paper presents the results of the fourth iteration of the EDGE (Early Development of General Engineering) Summer Bridge Program that was initiated in $2003^{1}$. This year the project was completely supported by a grant (MSEIP \#P120A050080) from the Department of Education.

\section{Brief History of the Program}

The original program was geared toward well-prepared high school students in the $10^{\text {th }}$ and $11^{\text {th }}$ grades who would have participated in the San Antonio Pre-freshman Engineering Program (PREP) ${ }^{2}$. EDGE introduced them to college level course work as a learning community and provided activities to help them develop independent learning and teamwork skills with the goal of increasing their likelihood of earning a college degree in engineering, science, math, or other related field. The learning community courses offered were Introduction to Engineering and College Algebra. The number of applicants eligible for College Algebra was disappointingly low (32\%). This prompted us to change the way we advertised and structured the program for the second year.

The change in marketing strategy was effective, and the number of applications increased considerably from the first year. However, only half of all applicants met college admission requirements, and an even smaller fraction of them qualified for College Algebra. The learning community courses offered were Introduction to Engineering and Computer Literacy. While the results of the 2004 Program were good, they were not quite as good as the 2003 Program, and students were not sufficiently challenged by the Computer Literacy course $^{3}$. This prompted us to return to our original program design for 2005, with a single track offering College Algebra and Introduction to Engineering, and to add $12^{\text {th }}$ graders to our targeted student population. The results of this strategy also fell short of expectations and we decided to again offer Introduction to Engineering and a slightly more rigorous version of Computer Literacy as the learning community courses. As before, the coursework was supplemented by computer assisted Math sessions in the afternoon ${ }^{4}$.

For 2006, the program was revised to address shortcomings of previous years, and extended to provide opportunity for student involvement over the entire school year. The Computer Literacy course was replaced with an enhanced Conceptual Physics course and the afternoon computer assisted math training was extended and made mandatory. An enhanced fall semester Saturday College Algebra course was offered to all qualified current and previous EDGE students, with the possibility to continue with a Pre-Calculus course offered on Saturdays during the spring 2007 semester.

\section{Program Details}

As in previous years, EDGE students were required to meet the same admission requirements as other college-level students, and paid only a \$25 entry fee. And like the previous eight week programs, students attended the two classes in the morning from 9:00 AM to noon, Monday through Friday with afternoon activities consisting of supervised study (SS1) and student success 
(SS2) sessions from 1:00 to 4:00 pm. This year the program accepted one group of thirty students that shared the same two classes. This cohort was split into ten teams for both classroom and afternoon activities. Study groups of two teams each were formed, each with a designated Study Leader trained in group learning methods (similar to Supplemental Instruction). The training emphasized the value of collaborative learning and peer support, and explained the purpose and function of Learning Communities. The SS1 sessions provided a supportive environment for students to work together on homework and group projects while building a sense of community and shared success. The SS2 sessions were one hour long and included the entire class, along with the SS1 Leaders. These sessions included workshops on study techniques, test taking, physics lab activities, and special presentations on topics pertaining to the field of engineering. There were also five field trips conducted to introduce students to engineering related activities in three privately owned local companies, one quasi-governmental agency, and the San Antonio College planetarium.

In terms of either numbers or percentages, the quantity of student applicants who have been academically prepared for College Algebra has remained so low that we have now abandoned our original concept of pairing it with the Introduction to Engineering course. However, our experience with replacing the College Algebra course with a Computer Literacy course appeared to be an over-correction, and this was also a disappointment. For the 2006 Program we introduced the conceptual level Introductory Physics course to replace College Algebra, and added several hands-on lab activities in the afternoon sessions. We also made the Plato Fastrack Advantage Program mandatory for one hour every afternoon to enhance students' math skills.

The same faculty member taught both courses of the program and made frequent correlations between course materials to show how they were related. Development of the learning community environment and management of the supervised study sessions was greatly facilitated by having the same instructor for both classes. The instructor also conducted daily meetings with Study Leaders to coordinate course assignments and afternoon activities.

\section{Enrollment Analysis}

Of the 98 applications submitted, 59 were received complete and only 35 met college admission requirements. The program commenced with 30 of these students actually enrolled. One student was lost due to a tragic accident and 29 students finished the program.

Complete Applications
Statistics
Female
Male
Hispanic / Latino
Asian / Pacific Islander
Non-Hispanic, Black
Non-Hispanic, White

\section{Accepted Applications Statistics}

16 Female

43 Male

43 Hispanic / Latino

1 Asian / Pacific Islander

5 Non-Hispanic, Black

10 Non-Hispanic, White

\section{Enrollment Statistics}

$\begin{array}{rlr}8 & \text { Female } & 7 \\ 27 & \text { Male } & 23 \\ 22 & \text { Hispanic / Latino } & 20 \\ 1 & \text { Asian / Pacific Islander } & 1 \\ 4 & \text { Non-Hispanic, Black } & 2 \\ 8 & \text { Non-Hispanic, White } & 7\end{array}$
7

Table 1: Enrollment analysis

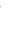




\section{Program Results}

All 29 students completing the 2006 Program received productive grades and college credit for both courses. The distribution of final grades is presented in Table 2 below.

\begin{tabular}{|cccccc|c|}
\hline A & B & C & D & F & W & $\begin{array}{c}\text { Productive } \\
\text { Grade Rates }\end{array}$ \\
\hline & & \multicolumn{2}{c}{ ENGR 1201 } & & & \\
7 & 16 & 6 & 0 & 0 & 1 & $96 \%$ \\
& & PHYS 1305 & & & \\
6 & 15 & 8 & 0 & 0 & 1 & $96 \%$ \\
\hline
\end{tabular}

Table 2: Final Grades posted for the entire group

The PLATO Fastrack Advantage program provided an assessment of students' math skills at the beginning and again at the end of the eight week session. The scores indicate a substantial gain in math skills for most of the students. The initial assessment indicated that only 6 students were above the $7^{\text {th }}$ grade Math level and 22 were below. The exit test showed a marked improvement: only one student remained below the $7^{\text {th }}$ grade Math level and 17 students were above $9^{\text {th }}$ grade Math level with the rest ranking in between. The average grade level improvement is shown in Table 3.

\begin{tabular}{|c|ccc|}
\hline Year & Initial grade level & Final grade level & Grade level increase \\
\hline 2006 & 3.30 & 9.35 & 6.35 \\
\hline 2005 & 3.78 & 7.58 & 3.80 \\
\hline
\end{tabular}

Table 3: Average PLATO Assessed Math Level Results

The more substantial grade level increase in the 2006 program can probably be attributed to the fact that one hour of every day was reserved for the PLATO Fastrack Advantage program, and this activity was directly supervised by the study group leaders. Since each group was composed of only six students, distractions were minimal.

The achievement of program outcomes related to students' interest in engineering was assessed through three surveys conducted during the eight week session. The first was administered on the first day of the program to assess students' existing knowledge of engineering and their familiarity with campus life. The second was administered after the last field trip to assess the impact of that program component, and a final questionnaire was administered the day before the closing ceremony to evaluate the entire program. The survey results are presented in the Appendix and summarized below in association with each program outcome (PO). 
PO-1) Students will develop a good understanding of student life and the particularities of being an engineering student, the nature of engineering work, and become familiar with the various engineering fields.

Results: Initially only nine students had an excellent or very good self-assessed knowledge of the engineering profession, and only ten had a very good knowledge of college life. The final survey indicates that a positive impact was made on 25 of the 30 students in the program. Increased knowledge of the engineering profession was reported by 24 students, and an outstanding or very good knowledge of the college life was reported by 20 students.

PO-2) The course materials and activities utilized in the program will be well correlated and useful in preparing students for success in science, technology, engineering, and mathematics.

Results: At the end of the EDGE Program the students as a group showed a substantial gain in average math skill grade level, although many students appeared to have already attained mastery of some course content (computer literacy). The two courses were well suited for a learning community linkage designed to provide knowledge, skills, and the peer support needed for academic success and a technical career. In the final survey 27 students considered the courses well coordinated and interconnected, and 26 declared that they would recommend the EDGE Program to other students.

PO-3) Students will experience academic success and student life in a college environment and begin to accumulate college course credits towards an Associate's degree at San Antonio College.

Results: All students completing the EDGE 2006 Program received productive grades and college credit for both courses.

PO-4) The EDGE Program will be effective in attracting and retaining high school students into the study of engineering and other technical fields (preferably at San Antonio College).

Results: In the final survey 16 students expressed an interest in continuing their studies with College Algebra in the Fall 2006 semester and 14 displayed a definitely or highly probable interest in a second stage of the EDGE Program, if one was available.

PO-5) The number of students returning to San Antonio College after attending previous EDGE Summer Programs is being monitored as an indicator of program's effectiveness. Enrollment of former EDGE students at SAC for the spring 2007 semester is presented in Table 4.

\begin{tabular}{|c|c|c|c|c|c|c|c|c|}
\hline \multirow{2}{*}{ EDGE cohort } & \multicolumn{2}{|c|}{2003} & \multicolumn{2}{c|}{2004} & \multicolumn{2}{c|}{2005} & \multicolumn{2}{c|}{2006} \\
\hline Majors & Engr. & Other & Engr & Other & Engr & Other & Engr & Other \\
\hline \# of students & 3 & 1 & 8 & 4 & 7 & 3 & 4 & 2 \\
\hline
\end{tabular}

Table 4: Spring 2007 Enrollment of EDGE Students at San Antonio College 
A brief review of other recruitment and retention programs for engineering around the country shows that similar problems have been encountered to various degrees and similar results have been achieved $^{5,6,7,8,9,10}$. This gives us confidence and reasons to continue refining our program model in order to improve our ability to attract and retain more students in math, engineering, science, and technology.

An overview of the application and enrollment history of the EDGE Program is presented in Table 5. Annual variations in program curriculum and promotion make annual comparisons difficult. The only discernible patterns appear in the last three years, with final student enrollment at about $50 \%$ of total applicants, and readiness for College Algebra at about $10 \%$ of accepted applicants.

\begin{tabular}{|lcccc|}
\hline \multicolumn{1}{|c}{ EDGE Cohort Year: } & $\mathbf{2 0 0 3}$ & $\mathbf{2 0 0 4}$ & $\mathbf{2 0 0 5}$ & $\mathbf{2 0 0 6}$ \\
\hline Complete applications received & 32 & 112 & 52 & 59 \\
Students accepted into the program & 20 & 62 & 35 & 35 \\
Students enrolled in the program & 20 & 58 & 26 & 30 \\
Students qualified for College Algebra & 7 & 6 & 3 & 4 \\
\hline
\end{tabular}

Table 5: EDGE Program Participation History

There are however some trends that appear to be well established: the strong positive response received after presentations at local high schools seems disproportionate to the relatively small number of applications received, and the academic preparation of students has consistently remained below expectations. The pressure to extend application deadlines in order to obtain a better pool of qualified students and to compensate for disparities in the timely reception of program information at some high schools has also continued, but we have acquired increased fortitude to stay within our published timelines. The development of a new EDGE web site is expected to be very helpful in disseminating timely information about the program ${ }^{11}$.

Perhaps the greatest challenge we continue to face in conducting this program is in recruiting and retaining competent group study leaders. The wages we can offer and the applicant screening criteria are strongly restricted by our centralized community college district administration. In 2006 we started advertising the positions earlier and were also able to hire an additional study leader to act as a coordinator. This provided a team environment for the study leaders which increased their individual effectiveness and augmented the overall success of the afternoon sessions.

Our original vision for the Program included a second phase EDGE II Program that would allow students to fully complete the bridge between their high school and college studies, leaving them ready for Calculus I. This goal has been out of reach because of the difficulties in obtaining enough students prepared for College Algebra. This year we developed an alternative strategy. With the cooperation of the Math Department, a College Algebra course was offered on Saturdays during the Fall Semester for all current and former EDGE students that were qualified and willing to enroll. The course was followed by a tutoring lab in the same day and the EDGE 
students met as a group with a study leader every week. A total of 12 students answered the call, five from the 2006 cohort and seven from the previous year. This class was also populated by 16 regular college students. The final course grade distribution for these two groups is presented in Table 6. Overall, the EDGE students performed slightly better than the regular students. Of the five EDGE students who successfully completed the College Algebra course, four indicated an intention to proceed to enroll in a Pre-Calculus course in the spring semester that will include the same support structure as the College Algebra course in the fall of 2006.

\begin{tabular}{|c|ccccccc|}
\hline $\begin{array}{c}\text { College Algebra } \\
\text { Results }\end{array}$ & A & B & C & D & F & W \\
\hline EDGE Students & 1 & 3 & 1 & 0 & 1 & 6 \\
Regular Students & 0 & 3 & 1 & 2 & 0 & 10 \\
Total & 1 & 6 & 2 & 2 & 1 & 16 \\
\hline
\end{tabular}

Table 6: Final Grades posted for the EDGE groups in College Algebra

Also with assistance from the Math Department, a one week intensive Math Boot Camp was offered to EDGE students who had not already qualified for College Algebra. Fourteen of them took the challenge and enrolled in this class. However, even after this special class, none were able to pass the ACCUPLACER at the end of the week. This situation, along with some other "discrepant events" related to this particular assessment tool noted over the years, raises some questions about the validity of the ACCUPLACER results that warrant further investigation.

For the EDGE 2007 Program we intend to maintain the same structure utilized 2006, with any enhancements needed in the Introductory Physics course to accommodate the Texas Essential Knowledge and Skills requirements for high school physics. This will allow EDGE students to receive both high school and college credit for the course. This feature is expected to increase the popularity of the program for 2007, and will hopefully improve our applicant pool statistics.

\section{Conclusions}

Although we have experimented with the two learning community courses each year, some of the greatest challenges associated with this program have been constant. Securing the commitment of a sufficient number of competent study group leaders continues to be a restricting factor. Finding appropriate faculty for the eight weeks in summer is also likely to constrain program growth. The large numbers of high school students with poor math skills continues to underscore the need for programs that can provide these students with the opportunity to improve their potential to achieve success in an increasingly global economy dependent on science, engineering and technology.

As in previous years, we remain indebted to the other members of our EDGE Executive Team, our college administration, and our funding sources. Their participation and support has enabled us to continue offering this program, and to make continuing improvements to help increase the number of high school students entering college with the intention and capability of achieving a degree in Engineering, Science, or Mathematics. 


\section{Bibliography}

1. Getting an EDGE in Engineering Education, by Jerry O'Connor and Dan G. Dimitriu, ASEE Conference, Salt Lake City, UT, June 2004

2. PREP - PreEngineering Program, URL: < www.prep-usa.org/portal/texprep/ >

3. A Strategy for Success: The EDGE Program in the Second Year, by Dan G. Dimitriu and Jerry O'Connor, ASEE Conference, Portland, OR, June 2005

4. The EDGE Summer Program in its Third Year, by Dan G. Dimitriu and Jerry O'Connor, ASEE Conference, Chicago, IL, June 2006

5. < www.msoe.edu/admiss/summer/index.shtml >

6. $<$ http://studentservices.engr.wisc.edu/diversity/esp/ >

7. < www.engr.ncsu.edu/summerprograms/index $2 . h t m l>$

8. < www.seas.virginia.edu/minority/ite.htm $>$

9. < www.engineering.cornell.edu/diversity/office-diversity-programs/summer-programs/index.cfm >

10. Bringing "Engineering Forward" To The High Schools: One University's Experience In Starting An Engineering Summer Camp Program, by Bryen E. Lorenz, Frontiers in Education Conference, Savannah, GA, October 2004.

11. < http://www.accd.edu/sac/edge/default.htm > 


\section{APPENDIX}

\section{Survey Results:}

\begin{tabular}{|c|c|c|c|c|c|c|c|c|}
\hline & INITIAL SURVEY - \# OF STUDENTS - 30 & 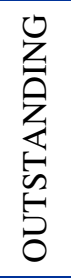 & 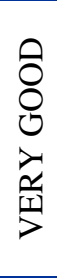 & $\begin{array}{l}\frac{1}{0} \\
\frac{\pi}{\pi} \\
\frac{\pi}{4}\end{array}$ & 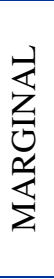 & $\begin{array}{l}\text { 岁 } \\
\text { ○ } \\
\text { 乙 }\end{array}$ & 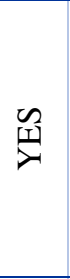 & Z \\
\hline 1 & Knowledge Of The EDGE Program & & 8 & 17 & 4 & 1 & & \\
\hline 2 & Knowledge Of College Life & 1 & 9 & 16 & 4 & & & \\
\hline 3 & Knowledge Of The Engineering Profession & 2 & 7 & 12 & 6 & 3 & & \\
\hline 4 & Engineering Career Interest & 10 & 13 & 5 & 2 & & & \\
\hline 5 & Math Performance & 7 & 13 & 8 & 2 & & & \\
\hline 6 & Physics Performance & 3 & 2 & 13 & 9 & 3 & & \\
\hline 7 & Participant In Similar Programs & & & & & & 13 & 17 \\
\hline
\end{tabular}

\begin{tabular}{|c|c|c|c|c|c|c|c|c|}
\hline & FINAL SURVEY - \# OF STUDENTS - 29 & 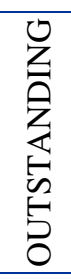 & 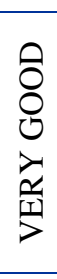 & 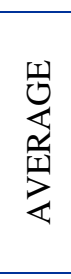 & 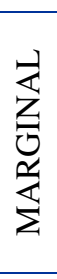 & $\begin{array}{l}\text { 崩 } \\
\text { 乙 }\end{array}$ & $\stackrel{\mathscr{I}}{\underline{\lambda}}$ & $\stackrel{0}{Z}$ \\
\hline 1 & Rating Of The EDGE Program & 12 & 11 & 5 & 1 & & & \\
\hline 2 & Knowledge Of College Life & 5 & 15 & 6 & 3 & & & \\
\hline 3 & Knowledge Of The Engineering Profession & 4 & 20 & 4 & 1 & & & \\
\hline 4 & Engineering Career Interest & 14 & 6 & 4 & 5 & & & \\
\hline 5 & Math Performance & 7 & 11 & 8 & 3 & & & \\
\hline 6 & Physics Performance & 4 & 4 & 16 & 4 & 1 & & \\
\hline 7 & EDGE Program Recommendation & & & & & & 26 & 3 \\
\hline 8 & Courses Were Well Coordinated \& Interconnected & & & & & & 27 & 2 \\
\hline 9 & \multicolumn{6}{|l|}{ Gained From This Program } & 25 & 4 \\
\hline & FINAL SURVEY - \# OF STUDENTS - 29 & 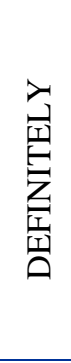 & 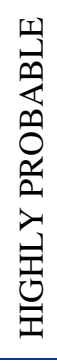 & 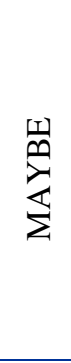 & 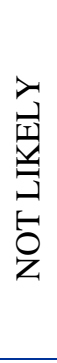 & そ & & \\
\hline 10 & Interested In The Fall 2006 EDGE Program & 12 & 4 & 6 & 6 & 1 & & \\
\hline 11 & Interested In A Second Level EDGE Program & 10 & 4 & 10 & 5 & & & \\
\hline
\end{tabular}




\begin{tabular}{|c|l|c|c|c|c|c|}
\hline$\#$ & \multicolumn{1}{|c|}{ FIELD TRIPS SURVEY - 25 } & $\begin{array}{c}\text { STRONGLY } \\
\text { DISAGREE }\end{array}$ & DISAGREE & NEUTRAL & AGREE & $\begin{array}{c}\text { STRONGLY } \\
\text { AGREE }\end{array}$ \\
\hline 1 & Trips Were Informative & 1 & 1 & 4 & 16 & 3 \\
\hline 2 & $\begin{array}{l}\text { Site Guides Were Knowledgeable \& } \\
\text { Helpful }\end{array}$ & 1 & 0 & 9 & 10 & 5 \\
\hline 3 & $\begin{array}{l}\text { Trips Supported The EDGE Program } \\
\text { Objectives }\end{array}$ & 1 & 2 & 1 & 18 & 3 \\
\hline 4 & $\begin{array}{l}\text { Trips Supported Continuing A College } \\
\text { Education }\end{array}$ & 1 & 2 & 7 & 11 & 4 \\
\hline 5 & Trips Were Satisfactory & 2 & 2 & 2 & 17 & 2 \\
\hline
\end{tabular}

